\title{
Gender Equality and Economic Development \\ The Role for Information and Communication Technologies
}

\author{
Derek H. C. Chen * \\ The Knowledge for Development Program \\ The World Bank \\ Washington DC 20433
}

\begin{abstract}
This paper focuses on the role that information and communication technologies (ICTs) can play in improving gender equality, so as to enhance long-term economic growth. Employing OLS and IV panel regressions with country fixed-effects, the paper shows that increases in the level of ICT infrastructure tend to improve gender equality in education and employment. In addition, it shows that education among the general population is important for improving gender equality. The results provide evidence indicating that gender equality in education is an important contributor to gender equality in employment. Lastly, the results show that economic development itself tends to lead to some improvements in gender equality in the labor market. Hence, the use of ICTs to improve gender equality in education and employment may initiate a continuous cycle of positive reinforcing feedback effects between gender equality in employment and economic development, leading to further improvements in both.
\end{abstract}

World Bank Policy Research Working Paper 3285, April 2004

The Policy Research Working Paper Series disseminates the findings of work in progress to encourage the exchange of ideas about development issues. An objective of the series is to get the findings out quickly, even if the presentations are less than fully polished. The papers carry the names of the authors and should be cited accordingly. The findings, interpretations, and conclusions expressed in this paper are entirely those of the authors. They do not necessarily represent the view of the World Bank, its Executive Directors, or the countries they represent. Policy Research Working Papers are available online at http://econ.worldbank.org.

*The Knowledge for Development Program of the World Bank Institute. I am grateful to Carl Dahlman for suggesting this research topic. 


\section{Table of Contents}

\section{Introduction}

2. Gender Inequality Around the World

3. Gender Inequality and Economic Development

4. ICT and Gender Inequality

4.1 ICTs and Economic Development

4.2 Improving Gender Equality with ICTs

5. Other Determinants of Gender Inequality

5.1 Determinants of Gender Inequality in Education

5.2 Determinants of Gender Inequality in Employment

6. Empirical Methodology

6.1 Definitions of Variables and Sources of Data

6.2 Econometric Methodology

7. Estimation Results

7.1 Gender Inequality in Education

7.2 Gender Inequality in Employment

\section{Concluding Remarks}

\section{References}

Figures

Tables 


\section{Introduction}

It has become widely understood that promoting gender equality is an essential component of an effective economic and human development strategy. For example, World Bank (2003a) reports:

"There is now a shared understanding within the development community that development policies and actions that fail to take gender inequality into account and fail to address disparities between males and females will have limited effectiveness and serious cost implications."

World Bank (2003a), p. 4

Historical data reveal that there is a statistically significant positive association between gender equality in education and economic development. Figure 1 presents the scatter plot and the linear regression line of the ratio of female to male literacy rates in year 2000 against the level of per capita GDP (PPP adjusted) in 2000. It can be seen that the ratio of female to male literacy rates tends to be positively associated with levels of GDP per capita. Similarly, Figure 2 shows that an alternative measure of gender inequality in education, the ratio of female to male students in primary and secondary schools, also tends to have a statistically significant positive association with economic development.

Further, Abu-Ghaida and Klasen (2002) provides empirical evidence indicating that a country failing to close the gender gap in education could experience a decrease in per capita income by 0.1 to 0.3 percentage points. Similarly, the Arab Human Development Report 2002 concludes that the low empowerment of women is one of the factors that have seriously hampered human development in the region over the last three decades (United Nations, 2002). In view of the above, issues surrounding gender equality need to be addressed for effective and sustainable economic and human development.

Given the importance of gender equality to economic development, this paper focuses on improving gender equality in education and employment using information and communications technologies (ICTs). With their ability to overcome geographical boundaries and relatively low access costs, ICTs have revolutionized the transfer of information and knowledge around the world. Enabling women to acquire education through distance learning, or allowing women to telecommute and hence participate in the labor market from their homes are just two common examples of how ICTs can help in improving gender equality. Using five different indicators of the level of the ICT infrastructure and estimating OLS and IV panel regressions with country fixed-effects, this paper presents robust results indicating that improvements in the ICT infrastructure 
tend to improve gender equality in education and employment. Further, this paper also shows that reducing gender inequality in education also reduces gender inequality in employment, which implies that improving ICT infrastructure or ICT availability improves gender equality in the labor market via both direct and indirect means.

This paper is laid out as follows. Section 2 reviews the status of gender inequality around the world, and shows that while the situation is improving, gender inequality still persists in all regions of the world. Section 3 reviews the literature documenting empirical evidence of the effects of gender inequality on economic development. This section also presents the various channels via which gender inequality in education and employment tends to reduce economic growth. The various characteristics of ICTs, and how a higher level of ICT infrastructure facilitates economic development and improves gender equality are discussed in Section 4. Section 5 briefly mentions the other possible determinants of gender equality in education and employment. Section 6 presents the definitions of variables used in the regressions, and a description of the econometric methodology. The main estimation results are highlighted in Section 7 and Section 8 provides some concluding remarks.

\section{Gender Inequality Around the World}

World Bank (2001) reports that gender inequality in various forms is still prevalent around the world. Using an index of gender inequality, Figure 3 illustrates the persistence of gender inequality in basic rights in every region of the world, including the developed OECD countries ${ }^{1}$. It should be noted that gender equality in basic rights tends to be weaker in the poorer regions of the world. This indicates that gender equality tends to improve with economic development, a point that will be revisited below.

Figure 4 focuses on gender inequality in education and presents the female to male ratio of the youth literacy rates of the various regions. It can be seen that from 1990 to 2002 , the ratio has been consistently increasing in all regions of the world, indicating an improvement in gender equality in education. Note that gender equality in education in the South Asia, Sub-Saharan Africa and the Middle East and North Africa regions has been consistently below the global average. In the 2002, the ratios were 79 percent, 89

\footnotetext{
${ }^{1}$ The rights indicator is an average of three indexes of gender equality in rights collected for more than 100 countries by Humana (1992). The individual rights indexes focus on gender equality of political and legal rights, social and economic rights, and rights in marriage and in divorce proceedings. The indexes are constructed using a consistent methodology across countries in which the extent of rights is evaluated (on a scale of 1 to 4) against rights specified in several human rights instruments of the United Nations.
} 
percent and 87 percent in South Asia, Sub-Saharan Africa and Middle East and North Africa, respectively.

Figure 5 presents another indicator of gender inequality in education: the ratio of female to male students in primary and secondary schools. As with the ratio of youth literacy rates, all regions show an increase in the student ratio in the previous decade, which again depicts an improvement in gender equality in education. This measure also reveals South Asia, Sub-Saharan Africa, and Middle East and North Africa to be weaker in gender equality than the rest of the regions.

An alternative but equally important aspect of gender inequality is that of employment. Figure 6 indicates that the female share of the labor force for the various regions of the world. As with the indicators of gender inequality in education, the female share of the labor force has been increasing in all regions over the period from 1990 to 2002. It is also the case that some regions are more employment gender equal than others. Even though there has been consistent improvement for the 1990-2002 period, Latin America and the Caribbean, South Asia and the Middle East and North Africa have experienced more gender inequality in the labor market than the global average.

In summary, we see that while gender equality in education and employment has been substantially improving over time, the gender gap still persists in all regions of the world today. The next section discusses the consequences of not eliminating gender inequality on economic development.

\section{Gender Inequality and Economic Growth}

It was mentioned in Section 1 and that Figures 1 and 2 depict a clear statistically significant positive association between gender inequality (in education) and the level of economic development. This section will discuss one possible direction for the positive association: improvements in gender equality lead to higher levels of economic development. Hence, this section will briefly review the existing empirical evidence indicating that gender equality tends to exert positive effects on economic growth. Various possible channels via which gender equality can affect economic growth will also be explored.

In recent years, the literature has produced evidence indicating the gender inequality tends have a negative effect on economic development. For example, Klasen (1999) finds that if countries of South Asia, Sub-Saharan Africa and the Middle East and North Africa had achieved gender equality in schooling during the period 1960 to 1992 as rapidly as in the East Asian countries, their income per capita could have grown by an 
additional 0.5 to 0.9 percentage point per year. For Africa, this would imply an almost doubling of per capita income growth.

Similarly, Dollar and Gatti (1999) examine the relationship between gender inequality in education and growth. Using data for over 100 countries, five-year growth intervals and two-stage least squares estimation, they find that larger female secondary education attainment tends to lead to higher growth rates, while male secondary achievement tends to lead to smaller growth rates. Alternatively, Hill and King (1993), using panel regressions for 152 countries during the period 1960-85, find that gender inequality in education has effects on the level of aggregate output. They find that a low female-male primary and secondary school enrollment ratio is associated with a lower level of GNP, even after controlling for the effects of female education on GNP.

The reasons for the negative effects on gender inequality on economic development are still disputed. However, there various channels put forth via which gender inequality in education and employment can have negative effects on economic development. As argued by Klasen (1999), three such possible channels are the selection distortion factor, the environment effect and the demographic transition effect.

\section{The Selection-Distortion Factor}

Assuming that boys and girls have very similar distribution of innate abilities, gender inequality in education must imply that less talented boys are able to acquire formal education, holding constant the capacity of schools. This consequently implies that the average innate ability of those who get educated is lower than it potentially would have been if boys and girls received equal educational opportunities. It thus follows that the resultant productivity of the labor force would be lower than the labor force productivity that would have been achieved, if there were no gender gap in educational enrollment. This lower labor productivity would in turn result in a lower rate of economic growth. ${ }^{2}$ Klasen (1999) suggests viewing this factor as similar to a distortionary tax on education that leads to a misallocation of education resources and thus lowers economic growth. In addition, a less productive workforce tends to decrease the rate of return to capital, which would consequently lower the investment rate and thus further lowering the rate of economic growth.

Similarly, gender inequality in employment generates a selection-distortion factor that operates at the level of the labor force. Gender gaps in employment tend to result in lower average labor force productivity than in the absences of such gender inequality in employment. As above, lower labor productivity tends to lower economic growth directly and indirectly via lower investment rates. (Figure 7)

\footnotetext{
${ }^{2}$ It should also lower the impact that male education has on economic growth and raise the impact of female education, as seen in Dollar and Gatti (1999).
} 


\section{The Environment Effect}

It has been documented that female education tends to improve the quantity and quality of education of children via the support and general environment an educated mother can provide her children. As such, because there would be effectively less female education at each level of male education, gender inequality in education has negative effects on the quality of overall education of the population, and consequently the labor force. In addition, there is some evidence indicating that similarity in educational levels at the household level tends to generate positive external effects on the quality of education. For example, as argued in Klasen (1999), it is likely that equally educated siblings can strengthen each other's educational success through direct support and play inspired by educational activities. Similarly, couples with similar educational levels may promote each other's life-long learning. In summary, having relatively more educated women tends to improve the intellectual environment at home, leading to a more productive workforce and higher economic growth. (Figure 7)

\section{The Demographic Transition Effect}

It is been found that high female education is one of the significant causal factors of fertility decline. This is because educated women tend to marry at a later age and also tend to increase the time intervals between pregnancies, and consequently giving birth to a smaller number of babies. Studies, such as Bloom and Williamson (1997), have also found that that lower fertility rates initiates a process known as the demographic transition, which may give rise to a transitory increase in the rate of economic growth via a sequence of events. First, reduced fertility tends to lower the youth dependency burden $^{3}$ and the total dependency burden ${ }^{4}$, which tends to increase the supply of aggregate savings within an economy. Second, lower fertility rates tend to over time result in a larger working-age population share because of previously high population growth. The resultant larger labor force will boost economic growth and investment demand. This higher investment demand, together with the aforementioned increased in domestic savings, will result in an increase in the investment rate, which should again increase economic growth.

${ }^{3}$ The youth dependency burden is defined as the ratio of the number of youths to the number of people in the working-age population. More specifically

$$
\text { Youth Dependency Burden }=\quad \frac{\text { persons of ages } 14 \text { years and younger }}{\text { persons of ages between } 15 \text { and } 64}
$$

4 The total dependency burden is defined as the ratio of the number of youths and the elderly to the number of people in the working-age population. More specifically

Total Dependency Burden=

$\underline{\text { (persons of ages } 14 \text { years and younger })+(\text { persons of ages } 65 \text { years and older })}$ 
In light of the above, lower gender inequality in terms of higher female education would indirectly lead to a transitory increase in economic growth via demographic effects (Figure 8).

\section{Information and Communication Technologies and Gender Inequality}

Information and communications technologies in recent years have been recognized as an effective tool for promoting economic growth and sustainable development. With relatively low usage costs and its ability to overcome distance, ICTs have revolutionized the transfer of information and knowledge around the world.

The World Bank Group defines ICT to consist of hardware, software, networks, and media for collection, storage, processing transmission, and presentation of information in the form of voice, data, text, and images. They range from the telephone, radio and television to the Internet (World Bank, 2003b and c). On the other hand, the OECD defines ICT sectors as a combination of manufacturing and service industries that capture, transmit and display data and information electronically. Table 1 lists the ICT producing sectors under the OECD definition.

\subsection{ICTs and Economic Development}

Over the decade, there been a series of studies that show that both ICT production and ICT usage have contributed to economic growth ${ }^{5}$. ICT producing sectors have experienced major technological advancements, which have showed up as large gains in total factor productivity at level of the economy. As for the non-ICT producing sectors, investment in ICT has resulted in capital deepening, and hence increases in labor productivity. More importantly, various studies have produced empirical evidence suggesting that substantial productivity gains have been experienced from ICT usage ${ }^{6}$.

5 See Pilat and Lee (2001), Jorgenson and Stiroh (2000), Oliner and Sichel (2000), Whelan (2000), and Schreyer (2000).

${ }^{6}$ Some national studies point to the use of ICT as an important factor in improved TFP growth. For the United States, the Economic Report of the President (Council of Economic Advisors, 2000, 2001), Whelan (2000), Oliner and Sichel (2000) and Jorgenson and Stiroh (2000) attribute a considerable part of the increase in TFP growth to ICT-using sectors of the economy that do not produce ICT. For Australia, there is evidence that increased productivity has been accompanied by greater technology use, which includes use of ICT (Productivity Commission, 1999). There are also sectoral and firm studies that suggest that ICT investment has had positive impact on TFP. For examples in the distribution sector, see Readon et al. (1996), and Broersma and McGuckin (1999), while Brynjolfsson 
One of the most obvious benefits associated with ICT usage is the increased flow of information and knowledge. Because ICTs allow information to be transmitted relatively inexpensively and efficiency (in terms of cost), ICT usage tends to decrease reduce uncertainty and transactions costs of participating in economic transactions. This, in turn, tends to lead to increase in the volume of transactions leading to higher level of output and productivity. Moreover, with the increased flow of information, technologies can be acquired and adapted more easily again leading to increased innovation and productivity.

Apart from increasing the supply of information and knowledge, ICTs are able to overcome geographic boundaries. Therefore, as international buyers and sellers are increasingly able to share information, reduce uncertainty, reduce transactions costs, increase competitiveness across borders, all of which results in a more efficient global marketplace. Also, production processes can be outsourced, based on comparative advantage, across national boundaries resulting in further global efficiency gains. Market access and coverage also tend to expand, along with increased access to global supply chains.

With the increased information flows, ICT availability and usage tends to allow greater transparency, accountability and accessibility in the delivery of public services. In addition, the public becomes informed of their rights and increases their awareness of political and development processes that influence their lives. The informed constituency is thus able to pressure policymakers to be responsive to their interests and demands. Also, better institutions and governance has been shown to be a substantial factor in increasing long-term economic growth.

\subsection{Improving Gender Equality with ICTs ${ }^{7}$}

The unique characteristics of ICTs that have enabled it to be an effective tool for economic development also make them an effective mean through which gender equality can be improved. There are several ways in which an established ICT infrastructure or a high level of ICT availability can lead to improvements in gender equality.

and Kemerer (1996) and Gandal et al. (1999) indicate the existence of spillover benefits from ICT capital at the firm level.

${ }^{7}$ This section on the ways in which ICTs can improve gender equality borrows heavily from World Bank (2003c). 


\section{Influencing Public Opinion on Gender Equality}

Given that ICTs allow an increased flow of information and knowledge, increased availability and use of ICTs allow increased exposures to the customs, norms and practices of other cultures and societies. This in turn tends to increase awareness of issues surrounding gender inequality. As such, ICTs can be an invaluable tool in positively changing people's attitude, including women themselves, towards women by disseminating educational programs on gender equity. In addition, increased pressure from an informed constituency that are sensitive to gender inequality issues can also induce policymakers to include gender as an important component of their social and economic policies.

\section{$\underline{\text { Increasing Educational Opportunities for Females }}$}

Education tends to reduce gender inequality as it tends to broaden one's views, reduce ethnocentricity, and thus increase one's flexibility of accepting new customs and norms. Female education is especially important in societies where gender biases that dictate solely domestic roles for women. Lack of schooling in such cases tends to perpetuate gender disparities.

ICTs are able provide innovative ways for women to obtain and update their skills so as to enable them to participate fully and on a more equal bias in the economy. For example, ICTs allow various types and levels of education to be acquired through distance learning. Flexibility of access and study times and the potential to reach women in rural areas and/or women facing social barriers that limit their access to schools, make distance learning via ICT a promising educational approach for women. At the same time, education is also very important in improving the ability of women in developing countries to take full advantage of the opportunities offered by ICTs, especially those related to information technology. Currently, because of their low educational levels and limited access to scientific and technical education, many women in countries with strong gender biases tend to be poorly placed to reap the full benefits of these modern facilities.

\section{Increasing Economic Opportunities for Women}

ICT may open economic opportunities for women in cultures where they are expected to stay at home and are not permitted to have face-to-face contact with men other then close family, or to travel. In such cases, telephones, computers and the Internet allow women to telecommute, and hence work and interact with men without face-to-face contact, and even without being in the same place (Daly, 2003). Note that ICTs are useful for telecommuting even in cultures where domestic roles are not imposed on women. For example, many women in industrial countries that are gender egalitarian 
stay home voluntarily, so as play a larger role in their children's upbringing. In such cases, ICTs enable women to participate in the labor force without sacrificing their presence in the home.

It was mentioned above that ICTs facilitate commerce by increasing the flow of information, reducing transactions costs, overcoming distance and thereby increasing market coverage. These benefits are especially important to micro and small enterprises (MSE), which are dominated by women entrepreneurs. There have been reports of how self-employed women in Cambodia, India and Peru have exploited numerous economic opportunities offered by e-commerce (World Bank, 2003c).

\section{Other Determinants of Gender Inequality}

\subsection{Determinants of Gender Inequality in Education}

\section{Economic Development}

It was discussed in Section 1 that there exists a positive correlation between gender equality and economic development and this positive association was clearly illustrated in Figures 1 and 2. Several studies that presented evidence showing that improvements in gender equality in education lead to improvements in economic development were also reviewed. In this section, I argue that economic development also simultaneously exerts a positive causal effect on gender equality, which further reinforces the positive association between the two variables.

Several studies have presented evidence to this effect. Dollar and Gatti (1999) find empirical evidence indicating that increases in per capita income lead to reductions in gender inequality. They used focuses on four different types of measures of gender inequality: (1) access and achievement in education (2) improvement in health (3) indexes of legal and economic equality of women in society and marriage (4) measures of women's empowerment (representation in parliament, right to vote). Easterly (1997) estimates fixed effects panel regression in which the gender variable is the female to male secondary school enrollment ratio and the only right-hand side variable is per capita income. He shows that there is a positive relationship between income and gender equality. His work establishes that the correlation between income and gender equality in secondary education is not simply a cross sectional association, but in fact true for individual countries as they develop. 


\section{Youth Sex Ratio}

The youth sex ratio, being a pure demographic variable, should not have any influence on the gender inequality in education. It is being included in the regressions as an independent variable to control for the effects of changes in the number of girls to boys in the population. Note that the variable being used to proxy gender equality in education in this empirical analysis, the ratio of female to male students in primary and secondary schools, tends to vary with the youth sex ratio and this variation is unrelated to changes in gender equality. For example, if the youth sex ratio of a specific country declines from 100 to 90 percent over a period of time, one would expect, in absence of a gender gap, the student ratio to decline from 100 to 90 percent as well. Inclusion of the youth sex ratio as a control variable thus ensures that changes in the student ratio due to changes in the youth sex ratio are properly accounted for. In light of the above, the youth sex ratio is expected to have a positive effect on the student ratio. More specifically, increases in the youth sex ratio are expected to lead to increases in the student ratio.

\section{Level of General Education}

It was argued above that education tends to broaden one's views, reduce ethnocentricity, and thus increase one's flexibility of accepting new customs and norms. As such, the level of education attained by the general population plays an important role in increasing acceptance of the concept of gender equality.

\section{Public Education Expenditure}

Public expenditure on education can potentially increase the number of females being enrolled in schools, other things being held constant. In an economy where the number of children exceeds the capacity of schools, increased public education expenditures can expand the capacity of schools, if the increased expenditures are used to say provide more classrooms and/or more teachers. If gender inequality exists in this society, then majority of the currently enrolled students will be boys and the female-tomale student ratio will be small. With additional capacity in schools, more children will be able to enroll in schools and if it is the case that majority of the male children in the population are already enrolled in schools, then it is likely that majority of the new incoming students will be female. This will tend to increase the female-male student ratio and hence increasing gender equality. In addition, studies have found that the female school enrollment is particularly sensitive to the costs associated with formal education. If public education expenditure is alternatively used to subsidize some or all of these costs, female school enrollment will increase relative to that of males.

However, it is also possible that the increased public education expenditure is not used to increase the capacity of schools or subsidize school fees or to provide textbooks. Fro example, if the additional public education expenditure is used instead to improve the quality of teachers via teacher training, then it is likely that there will be no effects on gender equality. In summary, while it is possible that increases in public education 
expenditure can increase gender equality in education, whether it does so in reality very much depends on how the additional resources are spent, which is likely to differ from country to country and from year to year. As such, the resultant effects of public education expenditure on gender equality a priori are at best indeterminate.

\subsection{Determinants of Gender Inequality in Employment}

\section{Economic Development}

Economic development may influence gender inequality in the labor market through the effects of the wages. As mentioned above, wages tend to increase with economic development and that this increases the opportunity cost of leisure or not working. As the opportunity cost increases, more people who were formerly not working will be induce to participate in the labor force. In a society with gender inequality in the labor market, the majority of the persons not working would be women, and hence it is likely that majority of the new entrants into the labor market would be women. Consequently, as the economy development, it is expected the gender equality in terms of labor force participation rates would increase.

\section{Level of General Education}

As above in gender inequality in education.

\section{Gender Equality in Education}

Gender equality in education is postulated to have positive effects on gender equality in employment. Given that education tends to increase one's human capital and thus productivity, it is intuitive that the more women are educated relative to men, the more women will be working relative to men. In addition, given the likely high positive correlation between gender equality in education and gender equality in employment, controlling for education gender equality in the employment gender equality regression ensures that the estimated coefficients of the independent variables are not simply reflecting effects of the independent variables on education gender equality.

\section{Urbanization Rate}

People residing in rural areas are generally more conservative and therefore have more rigid views with regard to traditional gender roles dictated by customs and norms. As such, increased urbanization rates may lead to higher levels of gender equality.

\section{Unemployment Rate}

In some countries, women tend to serve as secondary breadwinners of the family. In such cases, labor force participation rates of women may actually increase in period of high unemployment if the primary breadwinner is unemployed. Also, firms may prefer to hire female workers during economic recessions, as they are more likely to accept lower wages as compared to male workers. However, many women, especially in 
developed countries, participate in the labor market in a non-secondary breadwinner capacity. In such countries, high rates of unemployment should not have effects on gender equality in employment.

\section{Data and Empirical Methodology}

This section focuses on the econometric analyses of effects of ICT on gender inequality in education as well as gender inequality in employment. The sources and definitions of the variables used will be first presented and a description of the estimation methodology will then follow.

The data set underlying the gender inequality regressions attempts to include all of the 209 countries in the World Bank World Development Indicators (WDI) database for the years 1960 through 2002. However, due to missing observations, the number of countries and years included in the actual regression samples are significantly less. ${ }^{8}$

\subsection{Definitions of Variables and Sources of Data}

\section{Dependent Variables}

For the purpose of econometric estimation, this paper focuses a measure of gender inequality in education and a measure of gender inequality in employment. The ratio of girls to boys in primary and secondary education is used as a measure of the degree of gender inequality in education, while the ratio of the female to male labor force activity rates acts as the measure of gender inequality in employment.

1. Ratio of girls to boys in primary and secondary education: the percentage of girls to boys enrolled at primary and secondary levels in public and private schools. (Source: WDI)

2. Ratio of the female to male labor force activity rates: this ratio is constructed as the ratio of the female to male labor force crude activity rates. The female (male) labor force crude activity rate is expressed as a percentage of the total female (male) population of all age groups. Activity rate measures the labor force as a percentage of the working-age population. The labor force comprises people who meet the ILO definition of the economically active population: all people who

\footnotetext{
${ }^{8}$ Please refer to the tables of regression results for the number of countries and years included in each regression.
} 
supply labor for the production of goods and services during a specified period. It includes both the employed and the unemployed. While national practices vary in the treatment of such groups as the armed forces and seasonal or part-time workers, the labor force generally includes the armed forces, the unemployed, and first-time job seekers, but excludes homemakers and other unpaid caregivers and workers in the informal sector. (Source: WDI)

\section{Independent Variables - ICT Variables}

To determine the effects of ICT on gender inequality, five different indicators were used to proxy for the level ICT infrastructure or ICT density available within the economy. These measures are the number of computers per 1,000 persons, the number of Internet users per 1,000 persons, the number of telephones per 1,000 persons, ICT expenditure as a share of GDP and ICT expenditure per capita.

1. Number of Computers (per 1,000 persons): Personal computers are selfcontained computers designed to be used by a single individual. Computers per 1,000 population refers to the number of self-contained computers designed to be used by a single individual and is an indicator of personal computer penetration and use of relatively new technology for information processing. (Source: WDI)

2. Number of Internet Users (per 1,000 persons): Internet users are people with access to the worldwide network. (Source: WDI)

3. Number of Phones (per 1,000 persons): Telephones per 1,000 persons is the sum of telephone mainlines and mobile phones and provides a better indicator of connectivity than either in isolation. Telephone mainlines are telephone lines connecting a customer's equipment to the public switched telephone network. Mobile phones refers to users of portable telephones subscribing to an automatic public mobile telephone service using cellular technology that provides access to the public switched telephone network. (Source: WDI)

4. Information and communication technology expenditure (\% of GDP) (Source: WDI)

5. Information and communication technology expenditure per capita (US\$). Information and communications technology expenditures include external spending on information technology ("tangible" spending on information technology products purchased by businesses, households, governments, and education institutions from vendors or organizations outside the purchasing entity), internal spending on information technology ("intangible" spending on 
internally customized software, capital depreciation, and the like), and spending on telecommunications and other office equipment. (Source: WDI)

\section{Independent Variables - Control Variables}

\section{$\underline{\text { Regressions for Gender Inequality in Education }}$}

1. Per Capita Real GDP (Trend Value): HP Filtered Chain Weighted Per Capita Real GDP. This variable serves as a simple proxy for the level of economic development. It is adjusted for purchasing power parity so that values are comparable across different countries. The series is also adjusted using a chainweighted index to enable comparison across time periods. To account for the possibility of endogeneity, this variable was lagged by one year when used as an independent variable in the regressions. (Source: Penn World Table Version 6.1 website at http://pwt.econ.upenn.edu//) ${ }^{9}$ To remove cyclical fluctuations, this series is smoothed by apply the Hodrick-Prescott filter ${ }^{10}$.

2. Youth Sex Ratio: The youth sex ratio is defined as ratio of the number of females between the ages 0 to 14 to the number of males between the ages 0 to 14 , expressed as a percentage. Population numbers are based on the de facto definition of population, which counts all residents regardless of legal status or citizenship--except for refugees not permanently settled in the country of asylum, who are generally considered part of the population of the country of origin. (Source: WDI)

3. Average Years of Schooling: Average years of schooling of the total population, or equivalently average educational attainment, has been frequently used in the growth literature to proxy for the amount of education received by the population of a country ${ }^{11}$. There are two main global data sets on educational attainment. The first and probably more widely used data set is that of Barro and Lee (1993, $2001)^{12}$. This data set contains information educational attainment for persons

${ }^{9}$ See Heston and Summers (1991) and Heston, Summers and Aten (2002) for more details.

10 This is a smoothing method that is widely used among macroeconomists to obtain a smooth estimate of the long-term trend component of a series. The method was first used in a working paper (circulated in the early 1980's and published in 1997) by Hodrick and Prescott to analyze postwar U.S. business cycles. See Hodrick and Prescott (1997).

${ }^{11}$ For example, see Barro and Sala-i-Martin (1995), Barro (1997, 1999), Krueger and Lindahl (2000) and Temple (1999).

12 The Barro-Lee data set is based on school attainment figures obtained from UNESCO and they estimate missing values using data on school enrollment rates and the structure of population by age-groups. More specifically, their fill-in procedure uses the gross enrollment rate, adjusted for repeaters. Barro and Lee claim that this measure reflects the inflows of new school graduates to existing educational 
aged 15 years or older for many countries spanning the period 1960 to 2000 on a 5-yearly basis. There are 142 countries with at least one observation and 107 countries with complete information. The second global data set for average years of schooling is that of Cohen and Soto $(2001)^{13}$, which covers 95 countries and spans the period 1960 to 2000 on a decade basis. In order to obtain the broadest coverage of countries for data on educational attainment, we combined the information from Barro-Lee and Cohen-Soto data sets to obtain the resultant data set that covers 144 countries for the period 1960 to 2000 . If educational attainment data on a specific country is contained in both data sets, then the simple average of two data values were taken to obtain the final measure of the average years of schooling.

In view of the fact that the education level of the population tends to change very slowly and to enable the maximum number of observations to be included in the regression samples, a linear interpolation procedure was employed to fill in missing observations. This resulted in many countries have annual observations for the average years of schooling. To account for the possibility of endogeneity, this variable was lagged by one year when used as an independent variable in the regressions.

4. Public Expenditure on education per capita (US\$). Public expenditure on education consists of public spending on public education plus subsidies to private education at the primary, secondary, and tertiary levels. To account for the possibility of endogeneity, this variable was lagged by one year when used as an independent variable in the regressions.

stock more accurately than the traditional gross or net enrollment ratios. Their most recent version of the data set also takes into account changes of school duration over time within countries.

${ }^{13}$ This data set uses 3 main sources of data. They are the OECD database on education, national censuses or survey published by UNESCO's Statistical Yearbook and censuses obtained directly from national statistical agencies' web pages. Based on reports from its member and other non-member countries, the OECD has published detailed information on educational attainment, beginning at the end of the 1980s. This information refers to the population aged 15 to 64 broken up in different age groups and this is the cornerstone of the Cohen-Soto data set for high income countries. The main advantage of the OECD data set is that the information is presented in a standardized form across countries. Cohen and Soto extend the study performed by the OECD to missing periods and countries.

One key difference between the Cohen-Soto dataset is in the methodology for extrapolating the missing data. Barro and Lee extrapolate missing data for the whole population either backwards or forwards to obtain educational attainment for missing years. As opposed to using the whole population, Cohen and Soto utilize estimates for age-specific groups, which they argue tend to result in more reliable estimates. Cohen and Soto also claim that for some countries, they had more recent census information that that used by Barro and Lee. 


\section{$\underline{\text { Regression for Gender Inequality in Employment }}$}

1. Per Capita Real GDP (Trend Value): HP Filtered Chain Weighted Per Capita Real GDP. As above.

2. Urbanization Ratio: Urban population is the share of the total population living in areas defined as urban in each country, expressed as a percentage. To account for the possibility of endogeneity, this variable was lagged by one year when used as an independent variable in the regressions. (Source: WDI)

3. Unemployment Rate: Unemployment refers to the share of the labor force that is without work but available for and seeking employment, expressed as a percentage. Definitions of labor force and unemployment differ by country. (Source: WDI)

4. $\quad$ Average Years of Schooling: As above.

5. Female to Male Ratio of the Average Years of Schooling: This ratio is constructed as the ratio of the average years of schooling for females to that of male, expressed as a percentage. As with average years of schooling of the total population, the 5-yearly data for female and male average years of schooling were linearly interpolated to obtain annual observations, before the ratio was taken. (Source: Barro and Lee, 2001).

\subsection{Econometric Methodology}

Both OLS and IV panel regressions with country fixed-effects were estimated to investigate the effects of ICT infrastructure on gender inequality. Variables that proxy gender inequality were used as dependent variables, while ICT variables, along with other control variables, acted as independent variables. White's heteroskedasticity consistent standard errors were also employed.

\section{Ordinary Least Squares (OLS) Estimation}

To investigate the effects of ICT on the gender inequality in education, as measured by the ratio of female to male students in primary and secondary school, the following regression specification was estimated:

Student Ratio $_{i t}=\beta_{0}+\beta_{1} \log \left(\right.$ per capita real GDP $\left.{ }_{i, t-1}\right)+\beta_{2}\left(\right.$ Youth Sex Ratio $\left._{i t}\right)+$ $\beta_{3}$ (Average Years of Schooling $i, t-1$ ) $+\beta_{4}$ (Public Education Expenditure $\left._{i, t-1}\right)+\beta_{5} I C T_{i, t-1}$

where $i$ denotes country and $t$ denotes year. 
Similarly, to investigate the effects of ICT on the gender inequality in employment, as measured by the ratio of the female to male crude labor force activity rates, the following regression specification was estimated:

(Ratio of Labor Force Activity Rate $\left.{ }_{i t}\right)=$

$\beta_{0}+\beta_{1} \log \left(\right.$ per capita real GDP $\left._{i, t-1}\right)+\beta_{2}\left(\right.$ Urbanization Ratio $\left._{i, t-1}\right)+$

$\beta_{3}$ (Unemployment Rate $\left._{i, t}\right)+\beta_{4}$ (Average Years of Schooling $\left._{i, t-1}\right)+$

$\beta_{5}$ (Average Years of Schooling Ratio $\left._{i, t-1}\right)+\beta_{6} I C T_{i, t-1}$

where $i$ denotes country and $t$ denotes year. Note that the ICT variable may be in natural logarithmic terms.

\section{Instrumental Variable (IV) Estimation}

In an effort to properly account for possible endogeneity of a number of the independent variables, the equations for gender equality in education and employment were re-estimated using the instrumental variable (IV) technique. Pervious period lagged values were used as instruments. Variables in the education gender equality regressions that were instrumented are the real GDP per capita variable, average years of schooling, public education expenditure and all of the ICT variables. Variables in the employment gender equality regressions that were instrumented are the real GDP per capita variable, urbanization rate, average years of schooling, ratio of the average years of schooling and all of the ICT variables. As in the case of the OLS regressions, White's heteroskedasticity consistent standard errors were also employed.

\section{Estimation Results}

\subsection{Gender Inequality in Education}

Table 2 presents the OLS and IV panel regression results of estimating the education gender inequality equation (1) where the dependent variable is the ratio of the female to male primary and secondary students. As specified in Equation (1), all of the regressions in Table 2 include the same control variables, but each regression uses a different ICT variable to proxy for the level of ICT infrastructure existing with a specific country in a specific year. Due to missing observations for each of the variables, the number of observations included in the regression sample ranges from 415 observations in Reg 2.3 to 173 observations in Reg 2.5a. Similarly, the number of countries appearing the regression sample range from 46 countries in Reg 2.5 and 2.5a to 91 countries in Reg 2.2. The time period covered by the regression sample also varies. 
With regard to the estimated coefficients, it can be seen that all of the ICT variables exhibit estimated coefficients that are of the theoretically postulated positive sign and are highly statistically significant when using the OLS estimation. When the IV technique is employed, all of the ICT estimated coefficients remain positive and statistically significant. As such, both OLS and IV results indicate that increases in the level of ICT infrastructure, when measured by any of the five ICT variables, tend to increase the ratio of female to male (primary and secondary) school students, which indicates an improvement in gender equality in education.

It was postulated that the trend value of the real GDP per capita, which is a proxy for the level of economic development would be positively associated with the student ratio and gender equality. The results show that while all of the estimated coefficients of the trend real GDP per capita variable are positive, none are statistically significant. Lastly, we see that the estimated coefficients of the youth sex ratio all of the five regressions exhibit the theoretically expected positive sign and are highly statistically significant with both OLS and IV estimations.

Also, we note that the estimated coefficient of the average years of school variable is generally positive and statistically significant when estimated using OLS ${ }^{14}$. However, some these coefficients become statistically not significant with the IV estimation, even though they continue to be positive. This fact, coupled with the observation that for this average years of schooling variable most of the OLS coefficients are larger than the IV coefficients, hints at a problem of reverse causality. On the other hand, it is noted that this variable, even with IV estimation, still exhibits a highly statistically significant positive coefficient in Reg 2.1a and a (mildly) statistically significant positive coefficient in Reg 2.5a. Thus, the results indicate to a certain extent that the level of general education among the population tends to have a positive effect on gender equality in education.

Lastly, the education expenditure variable produces estimated coefficients that are generally not statistically significant; when OLS is used, the coefficient is positive and statistically significant only when the ICT variable being used is the ICT expenditure (either as a share of GDP or in per capita terms). When IV estimation is employed, only when the ICT variable is ICT expenditure per capita, is the coefficient of the education expenditure mildly significant. Given that the regression samples are much smaller in both of the regressions where the ICT variable is ICT expenditures, we should be cautious in attaching too much weight to statistical significance of coefficients of the public education expenditure variable in those regressions.

\footnotetext{
14 The only exception is Reg 2.3. Here the estimated coefficient of the average years of school variable is positive but not statistically significant at conventional levels.
} 


\subsection{Gender Inequality in Employment}

Table 3 presents the OLS and IV panel regression results of estimating the employment gender inequality equation (2) where the dependent variable is the ratio of the female to male crude labor force activity rates. As with the gender equality regression, all of the regressions in Table 3 include the same control variables, but each regression uses a different ICT variable to proxy for the level of ICT infrastructure existing with a specific country in a specific year. Because each variable has missing values for different years, the number of observations, the number of countries and the specific years that enter into the regression sample varies with each regression.

First, we see that the estimated coefficients of the ICT variables of both OLS and IV regressions, are consistently positive and statistically significant, with a single exception in Reg 3.4a. Hence, these results indicate that improvements in the level of the ICT infrastructure tend to lead to improvements in gender equality in employment as measured by the female to male ratio of the labor force activity rates.

The estimated coefficients of the real GDP per capita variable are consistently positive and are statistically significant in regressions Reg 3.2, 3.4 and 3.5. The coefficients continue to positive and statistically significant when estimated using IV techniques. The results therefore indicate to some extent that the trend real GDP per capita has a positive effect on the female-male ratio of labor force activity rates. Thus, this can be taken as evidence suggesting that economic development tends to have a positive influence on gender equality in employment as postulated.

As for the urbanization variable, we see that estimated coefficients are consistently not statistically significant and of varying signs. Similarly, the estimated coefficients of the unemployment rate are predominately not statistically significant and of inconsistent signs. On the other hand, both of the education variables produce estimated coefficients that were always theoretically consistent. More specifically, the average years of schooling variable has positive and highly statistically significant estimated coefficients with both OLS and IV estimations. This indicates that increases in the average years of schooling, which measures the level of general education among the population, tend to increase gender equality in the labor market. As for the female to male ratio of average years of schooling variable, the estimated coefficients that are mostly positive and statistically significant when using OLS, but the coefficients tend to become statistically not significant when IV estimation is employed. However, it is noted that this coefficient is still positive and highly statistically significant in Reg $3.3 \mathrm{a}$ and mildly significant in Reg 3.2a. Given that the female to male ratio of average years of schooling variable proxies for gender equality in education, the results thus provide limited empirical evidence showing that improvement in gender equality in education tends to improve gender equality in employment. This positive effect of gender equality 
in education onto gender equality in employment may thus provide a second indirect channel via which ICT availability is able to improve gender equality in employment ${ }^{15}$.

\section{Concluding Remarks}

Using OLS and IV panel regressions with country-fixed effects, this paper empirically assesses the effects of the level of information and communication technologies (ICT) infrastructure on gender inequality in education as well as in employment. Five indicators are used to proxy for the level of ICT infrastructure. They are the number of computers per 1,000 persons, the number of Internet users per 1,000 persons, the number of phones (both mainlines and mobile) per 1,000 persons, ICT expenditures as a share of GDP and ICT expenditures per capita. As for the gender inequality measures, the ratio of female to male students in primary and secondary schools is used as the measure for gender inequality in schools, while the female to male ratio of labor force activity rates acts as the proxy for gender inequality in the labor market.

The results indicate that the level of ICT infrastructure exerts a statistically significant positive effect on gender equality in education. This suggests that improvements in the level of ICT infrastructure lead to improvements in gender equality in education. It was also found that, to some extent, the level of education among the general population is important for improvement of gender equality in schooling.

The employment gender equality panel regressions reveal that the level of ICT infrastructure has a statistically positive effect on gender equality in employment. This implies that improvements in the level of ICT density tend to improve gender equality in the labor market as measured by the female to male ratio of the labor force activity rates. One possible reason for this positive effect is that the availability of ICTs enables women to telecommute and work from home. Another is that ICT use increases the flow of information and knowledge, and thus facilitates the changing of public opinion to accept the idea of women working.

It was also found that the prevailing level of education among the population has a statistically significant positive effect on gender equality in the labor market. It is postulated that education in general tends to broaden one's awareness of cultures and social norms that exist in other societies, and that in many of these societies, especially in industrial economies, females are in most circumstances entitled to the same freedoms and opportunities as extended to males. In addition, there was some evidence suggesting

\footnotetext{
${ }^{15}$ Recall that ICT availability is also able to improve gender equality in education.
} 
that gender equality in education, measured by the female to male ratio of the average years of schooling, also has a statistically positive effect on gender equality in employment. In other words, reduction in gender inequality in education shows signs of reducing gender inequality in the labor market. Lastly, the results also provide some evidence that economic development tends to increase gender equality in employment.

In summary, given existing evidence indicating that improving gender equality in education and employment leads to a higher level of economic development, this paper focuses on reducing gender inequality in education and employment by using ICTs. The paper shows that increasing ICT availability tends to reduce both gender inequality in education and employment. Further, this paper also shows that reducing gender inequality in education may also reduce gender inequality in employment, which may provide another channel for ICTs to improve gender equality in the labor market, thus increasing the economic importance of ICTs in improving gender equality. Lastly, the results show that economic development itself tends to lead to some improvements in gender equality in the labor market. Hence, the use of ICTs to improve gender equality in education and employment may initiate a continuous cycle of positive reinforcing feedback effects between gender equality in employment and economic development, leading to further improvements in both (see Figure 9). 


\section{References}

Abu-Ghaida, Dina and Stephan Klasen (2002). The Costs of Missing the Millennium Development Goal on Gender Equity. The World Bank, Washington D.C.

Baliga, S. S. Goyal, and Stepen Klasen (1999). "Education and Marriage Age: Theory and Evidence." University of Munich Discussion Paper. Munich: Department of Economics.

Barro, Robert J. (1997). Determinants of Economic Growth: Across-Country Empirical Study. Cambridge, Mass.: MIT Press.

Barro, Robert J. (1999). "Human Capital and Growth in Cross-Country Regressions." Swedish Economic Policy Review. Vol. 6, No. 2, pp. 237-277.

Barro, Robert and Jong-Wha Lee (1993). "International comparisons of educational attainment." Journal of Monetary Economics. Vol. 32, pp. 363-394.

Barro, Robert J. and Jong-Wha Lee (1994). "Sources of Economic Growth." Carnegie-Rochester Conference Series on Public Policy.

Barro, Robert J. and Jong-Wha Lee (2001). "International data on educational attainment: updates and implications." Oxford Economic Papers, Vol. 3, pp. 541-563.

Barro, Robert J., and Xavier Sala-I-Martin (1995). Economic Growth. New York: McGraw-Hill.

Bledsloe, Caroline (1990). Critical Perspectives on Schooling and Fertility in the Developing World. Washington D.C., National Academy Press.

Bloom, David and Jeffrey Williamson (1997). "Demographic Transition and Economic Miracles in Emerging Asia.” NBER Working Paper 6268.

Broersma, Lourens and Robert H. McGuckin (1999). "The Impact of Computer on Productivity in the Trade Sector: Explorations with Dutch Microdata." Research Memorandum GD-45, Groningen Growth and Development Centre, October.

Brynjolfsson, Erik and Chris F. Kemerer (1996). "Network Externalities in Microcomputer Software: An Econometric Analysis of the Spreadsheet Market." Management Science. Vol. 42, No. 4, pp. 1627-47. 
Cohen, Daniel and Marcelo Soto (2001). "Growth and Human Capital: Good Data, Good Results." Technical Papers No. 179, OECD Development Centre, September.

Council of Economic Advisors (2000). Economic Report of the President. United States Government Printing Office.

Council of Economic Advisors (2001). Economic Report of the President. United States Government Printing Office.

Dollar, David and Roberta Gatti (1999). "Gender Inequality, income, and Growth: Are Good Times Good for Women? Policy Research Report on Gender and Development, Working Paper Series, No. 1, The World Bank, May.

Daly, John A. (2003). "ICT, Gender Equality, and Empowering Women." Mimeo. Development Gateway website. July. (www.developmentgateway.org/node/133831/sdm/blob?pid=5233).

Easterly, William (1999). "Life During Growth.” Journal of Economic Growth. Vol. 4, No. 3 (September), pp. 239-76.

Gandal, Neil, Shane Greenstein and David Salant (1999). "Adoptions and Orphans in the Early Microcomputer Market." Journal of Industrial Economics. Vol. 47, pp. 97-116.

Hafkin, Nancy and Nancy Taggard (2001). "Gender, Information Technology, and Developing Countries: An Analytic Study." Mimeo. United States Agency for International Development (USAID). (www.usaid.gov/wid/pubs/it01.htm)

Hill, M. Anne and Elizabeth M. King (1993). "Women's Education in Developing Countries: An Overview." In Elizabeth M. King and M. Anne Hill (eds.) Women's Education in Developing Countries: Barriers, Benefits and Policies. The World Bank, John Hopkins University Press.

Hodrick, Robert J. and Edward C. Prescott (1997). "Postwar U.S. Business Cycles: An Empirical Investigation." Journal of Money, Credit and Banking. Vol. 29, No. 1 (February), pp. 1-16.

Humana, Charles (1992). World Human Rights Guide. 2nd ed. London: Hodder and Stoughton.

Jejeebhoy, Shireen (1995). Women's Education Autonomy and Reproductive Behavior: Experience from Developing Countries. Oxford University Press. 
Jorgenson, Dale W. and Kevin Stiroh (2000). "Raising the Speed Limit: U.S. Economic Growth in the Information Age." Brookings Papers on Economic Activity. Vol. 1, pp. 125-211.

Kirk, Dudley and Bernard Pillet (1998). "Fertility Levels, Trends, and Differentials in Sub-Saharan Africa in the 1980s and 1990s." Studies in Family Planning. Vol. 29, No. 1.

Klasen, Stephan (1999). "Does Gender Inequality Reduce Growth and Development? Evidence from Cross-Country Regressions." Policy Research Report on Gender and Development Working Paper Series, No. 7, the World Bank, November.

Krueger, Allan B. and Mikael Lindahl (2000). "Education for Growth: Why and For Whom?” National Bureau of Economic Research Working Paper No. 7591.

Oliner, Stephen D. and Sichel, Daniel E. (2000). "The Resurgence of Growth in the Late 1990s: Is Information Technology the Story?" Journal of Economic Perspectives. Vol. 14, No. 4 (Fall), pp. 3-22.

Pilat, Dirk and Frank C. Lee (2001). "Productivity Growth in ICT producing and ICT-Using Industries: A Source of Growth Differentials in the OECD?" STI Working Paper 2001/4. Organisation for Economic Co-operation and Development.

Productivity Commission (1999). Microeconomic Reform and Australian Productivity: Exploring the Links. Research Paper, AusInfo, Canberra.

Reardon, James, Ron Hasty and Barbara Coe (1996). "The Effect of Information Technology on Productivity in Retailing." Journal of Retailing. Vol. 72, No. 4, pp. 445461.

Schreyer, Paul (2000). "The Contribution of Information and Communication Technology to Output Growth: A Study of the G7 Countries." STI Working Paper 2000/2, Organisation for Economic Co-operation and Development, Paris.

Smith, Lisa C. and Lawrence Haddad (2000). "Explaining Child Nutrition in Developing Countries: A Cross-Country Analysis." Research Report 111, International Food Policy Research Institute. Washington D.C.

Temple, Jonathan (1999). "A Positive Effect of Human Capital on Growth." Economics Letters. Vol. 65, pp. 131-134. 
Thomas, D. (1990). "Intrahousehold Resource Allocation: An Inferential Approach.” Journal of Human Resources. Vol. 25, pp. 634-664.

United Nations (2002). Arab Human Development Report 2002: Creating Opportunities for Future Generations. United Nations Development Programme, Arab Fund for Economic and Social Development.

Whelan, Karl (2000). "Computers, Obsolescence, and Productivity." Finance and Economics Discussion Series. 2000-6, Federal Reserve Board, Washington, DC.

World Bank (1993). World Development Report. Washington, D.C.

World Bank (2001). Engendering Development. Washington, D.C.

World Bank (2003a). Gender Equality and the Millennium Development Goals. Washington, D.C., April.

World Bank (2003b). Engendering ICT: Ensuring Gender Equality in ICT for Development. Washington, D.C., September.

World Bank (2003c). ICT and MDGs: A World Bank Group Perspective. Washington, D.C., December. 
Figure 1

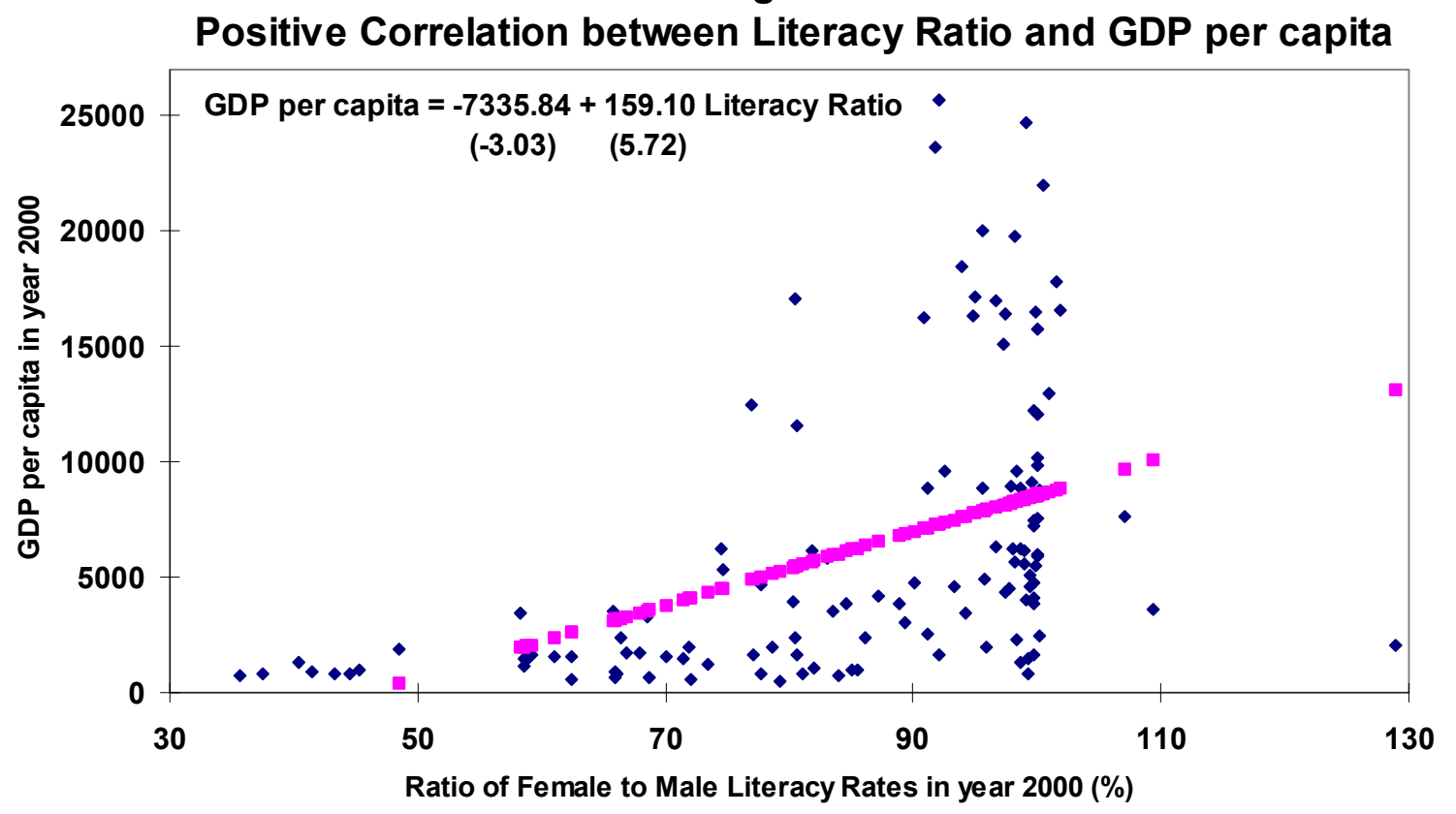

Figure 2

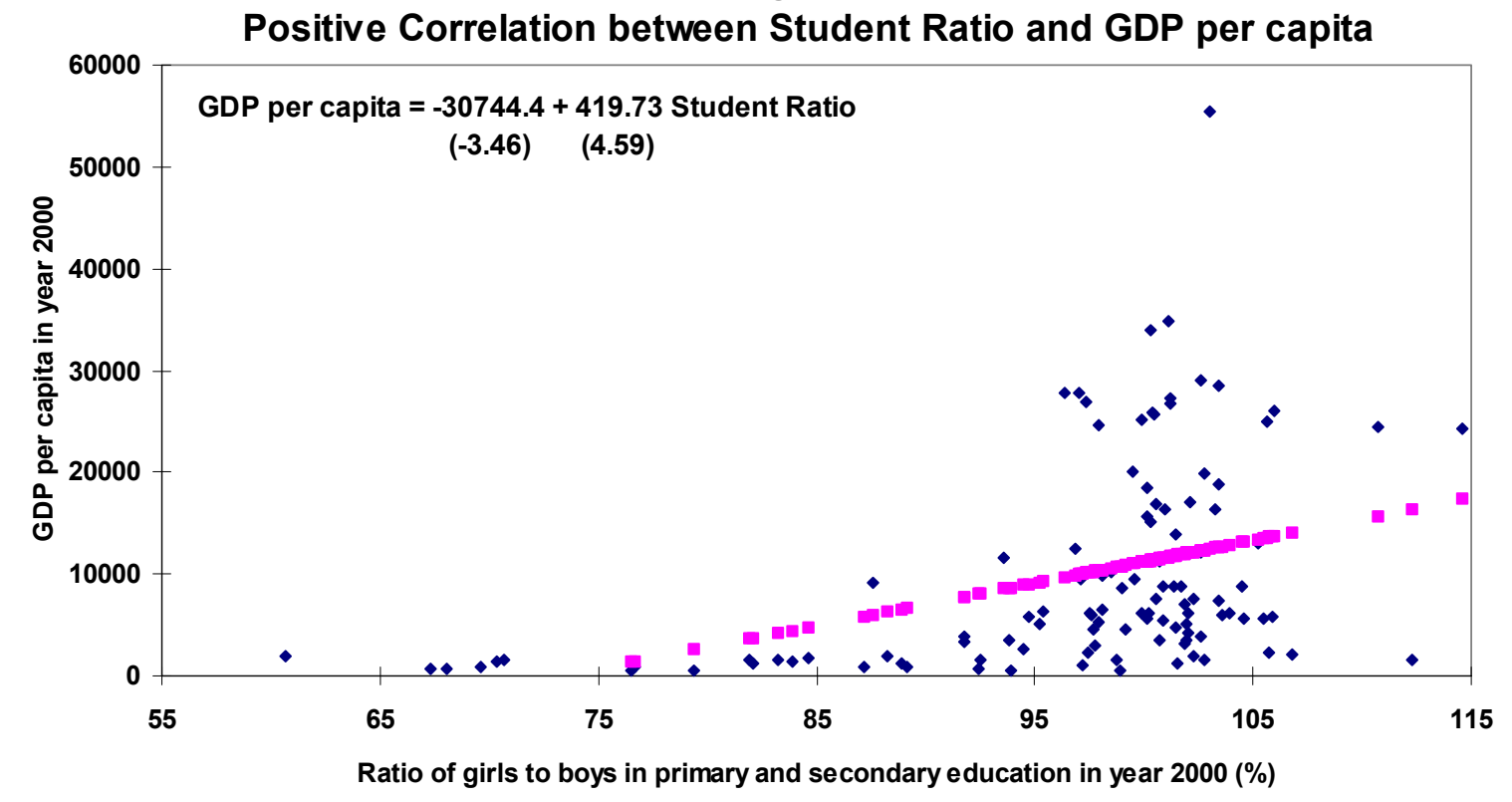




\section{Figure 3}

In No Region of the World are Women and Men Equal in Legal, Social or Economic Rights

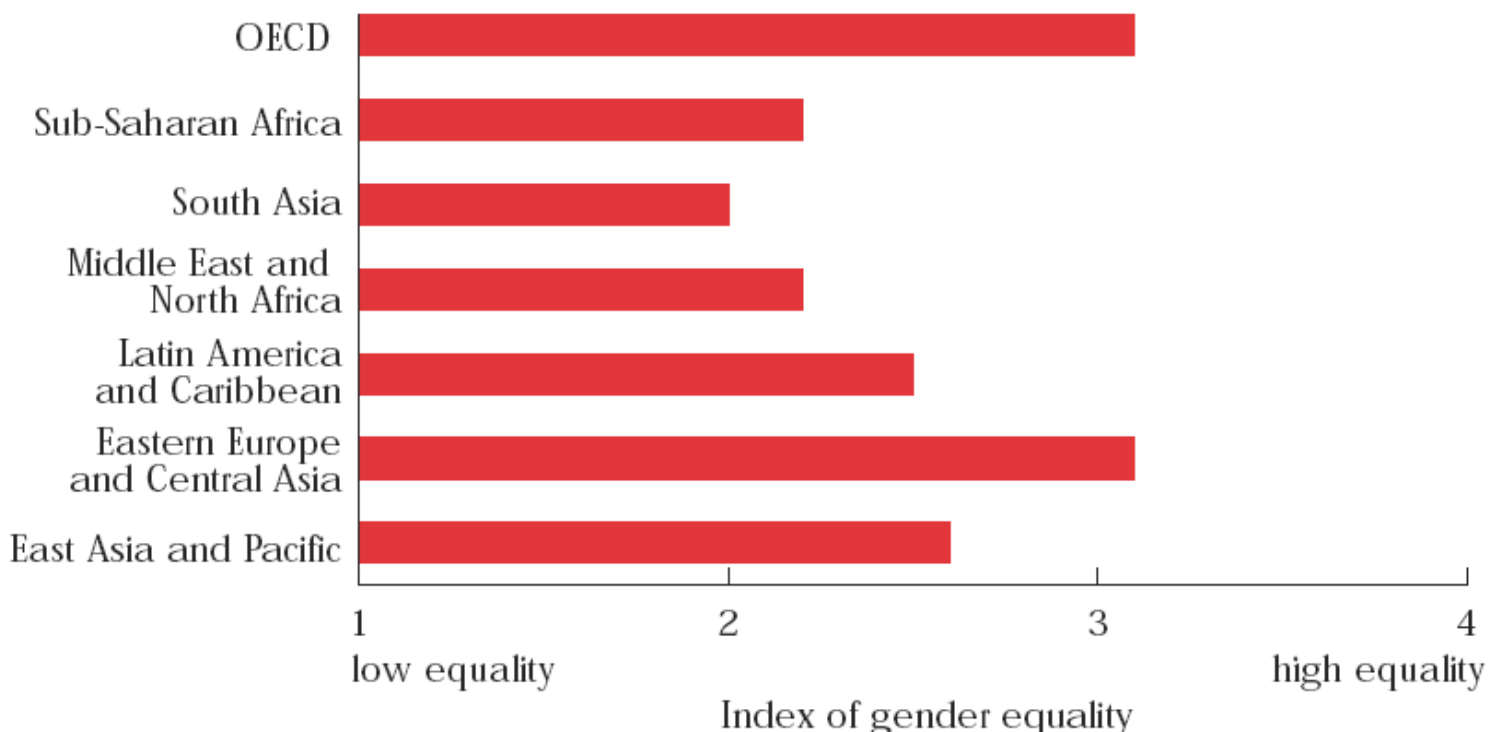

Source: Reproduced from World Bank (2003a)

Figure 4

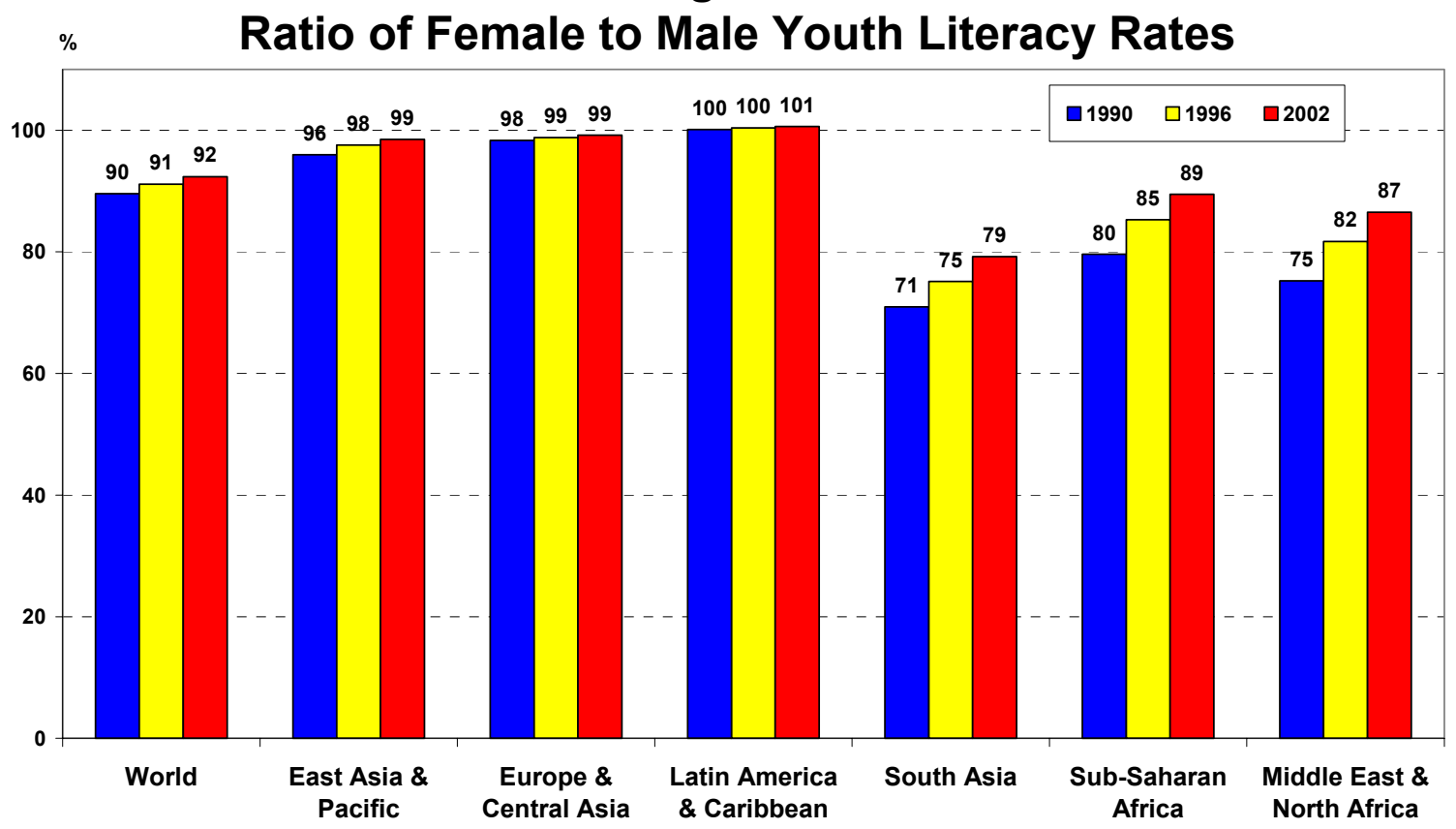


Figure 5

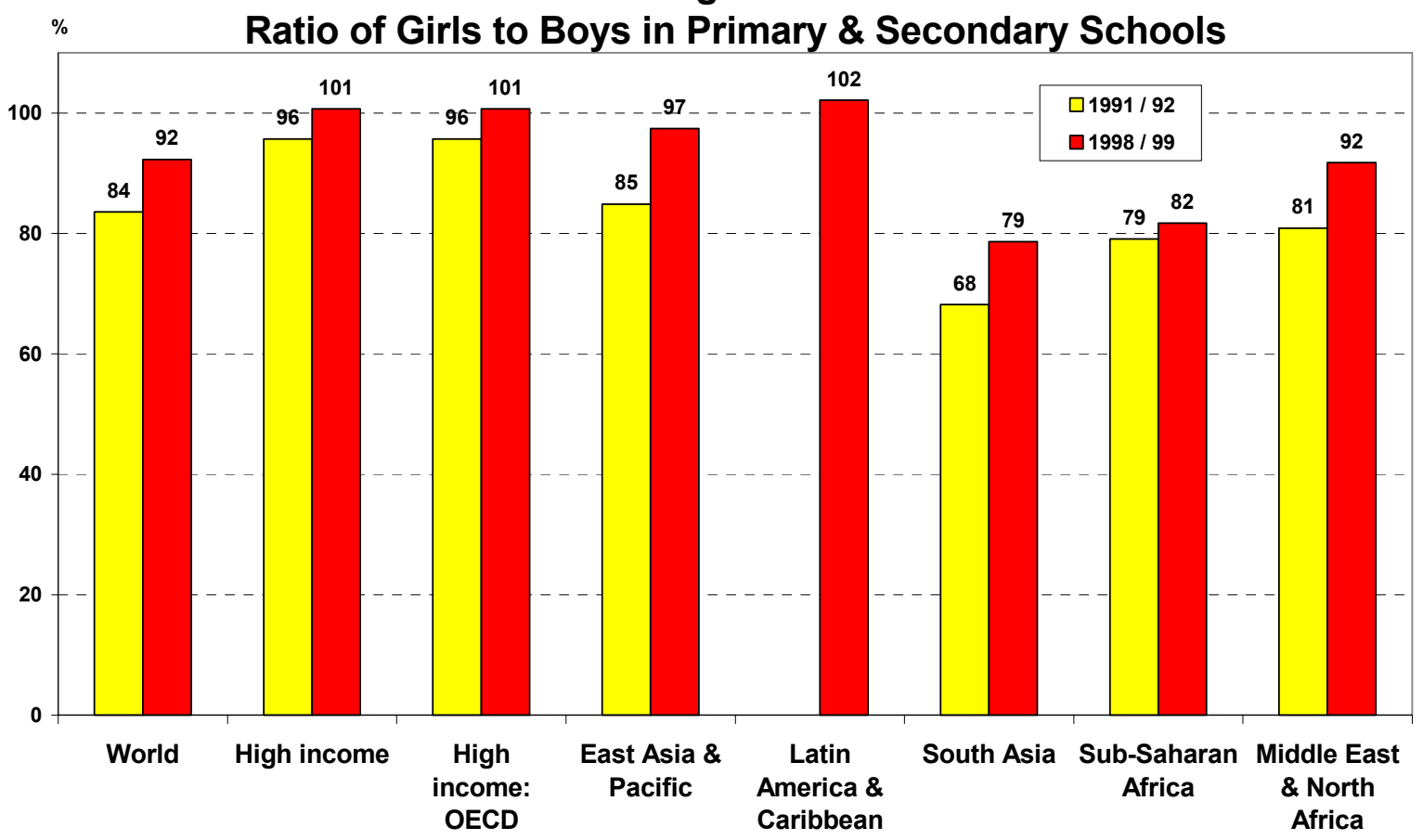

Figure 6

(\% of total labor force) $\quad$ Female Labor Force

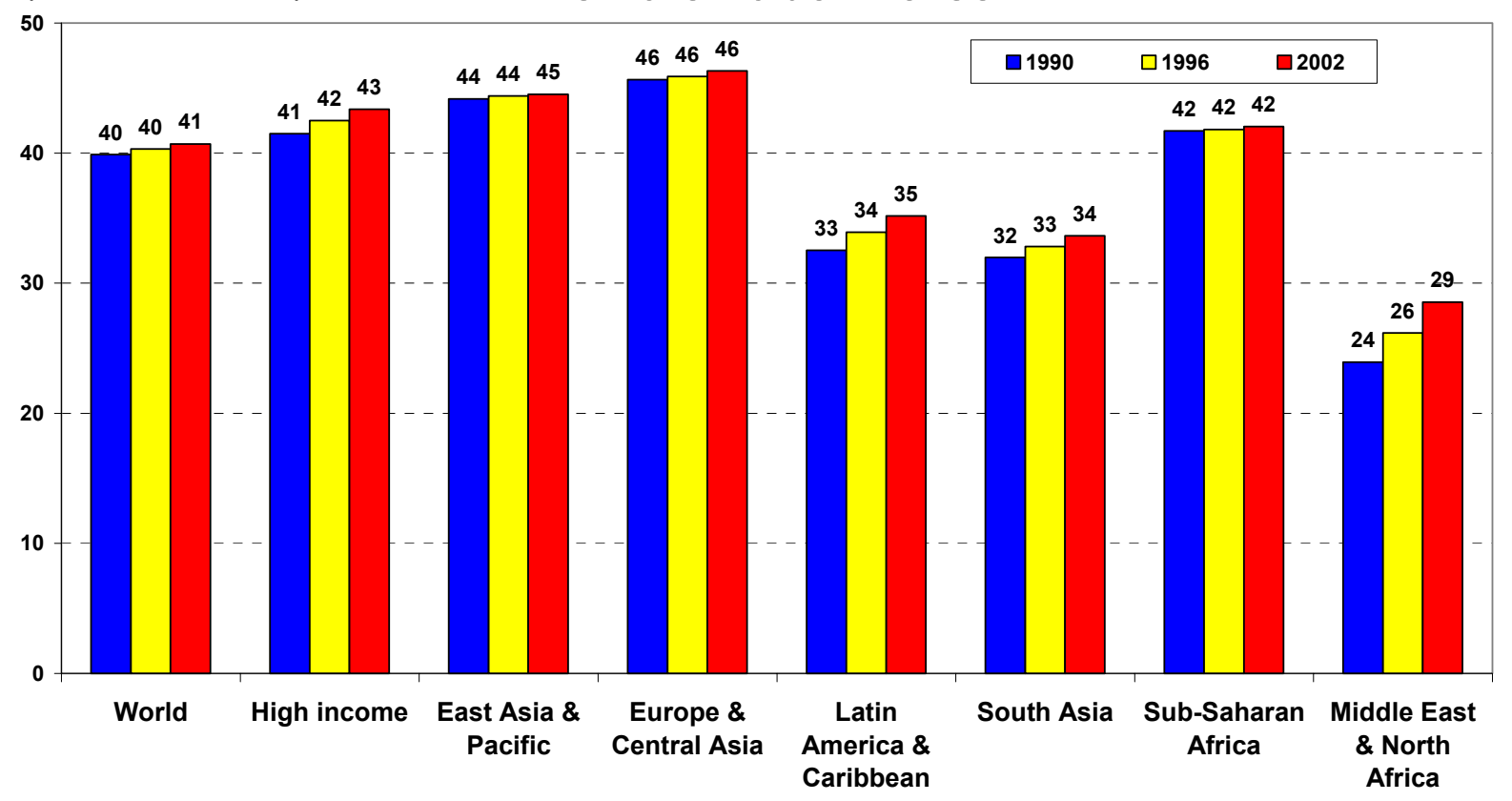




\section{Figure 7}

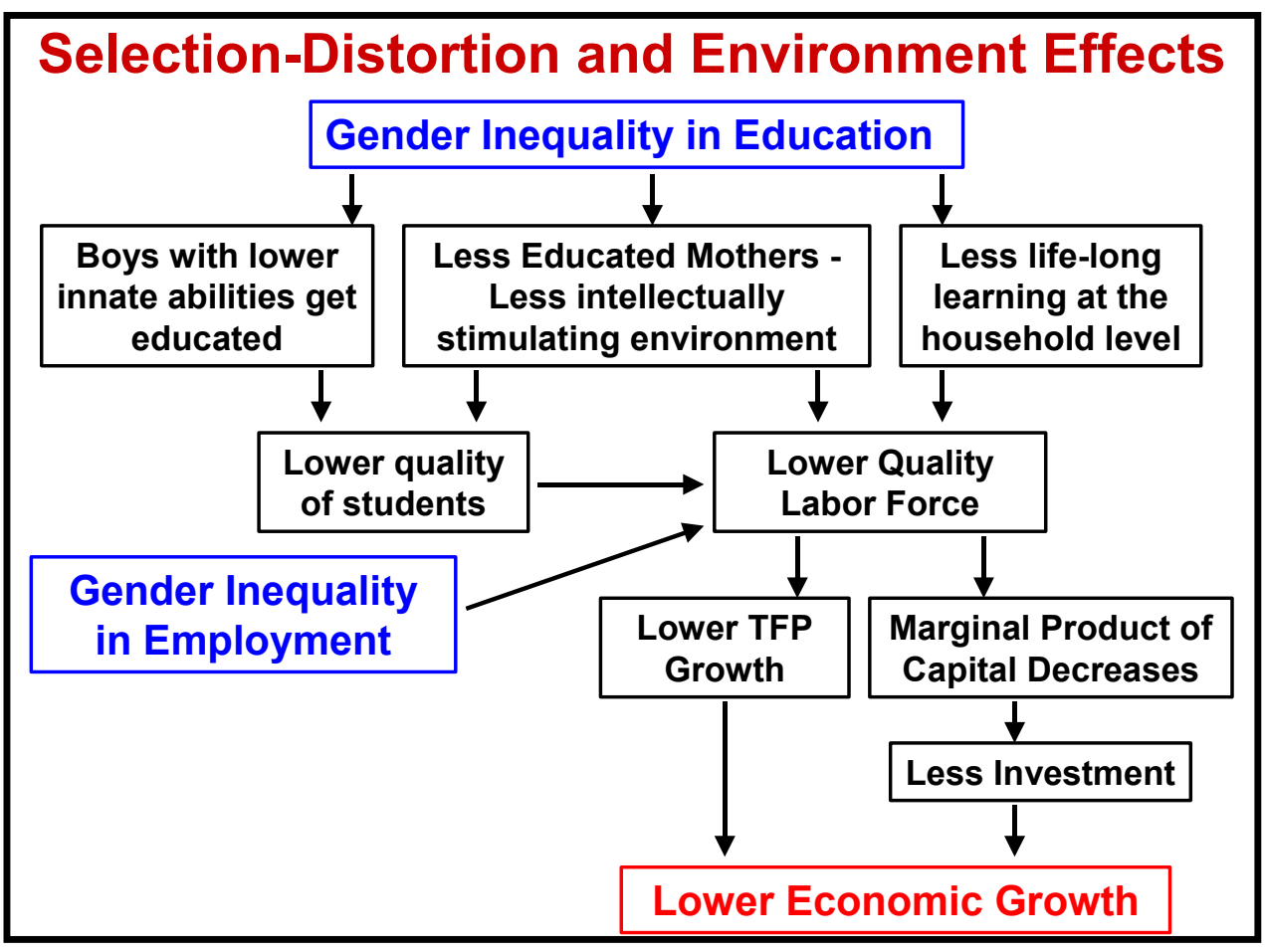

Figure 8

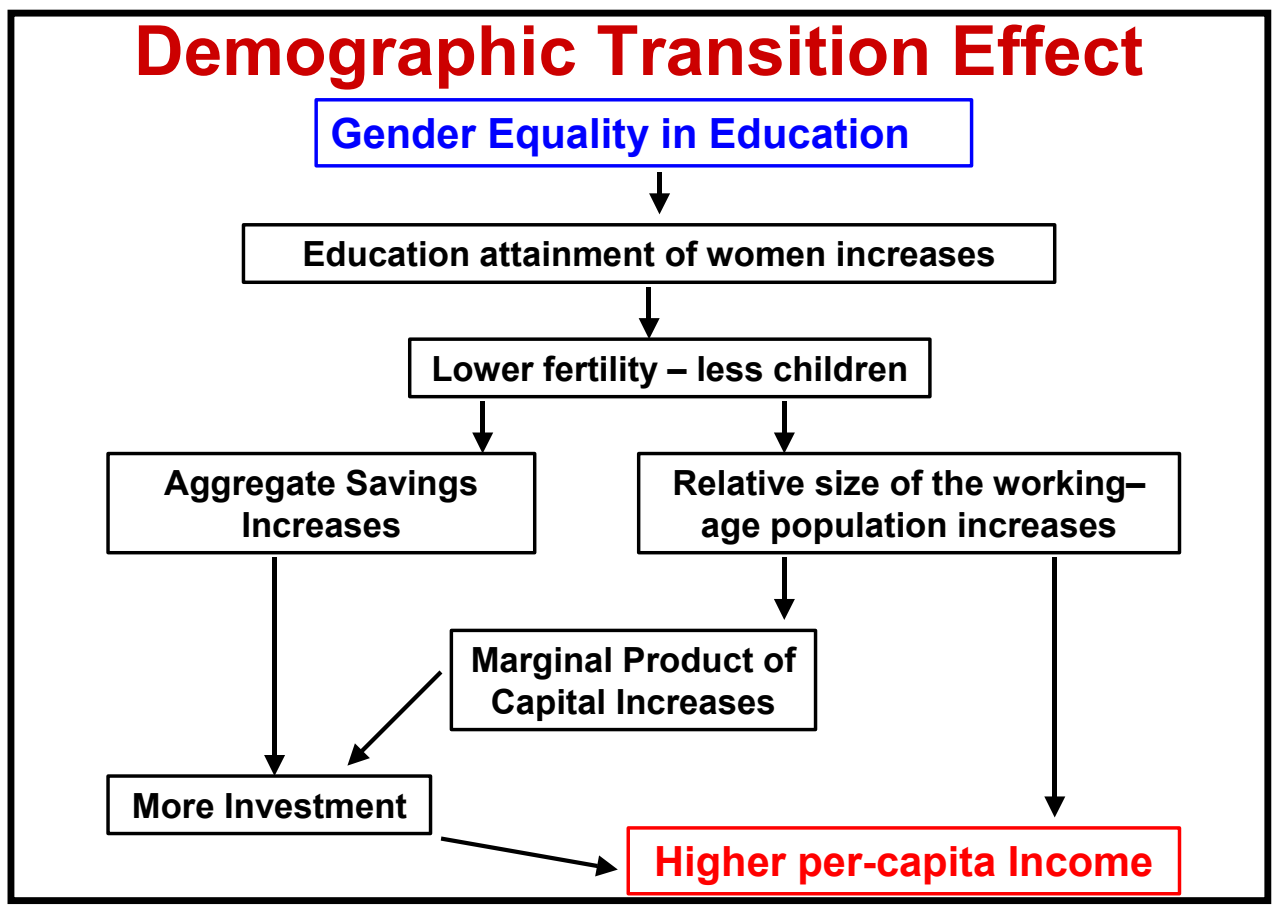


Figure 9

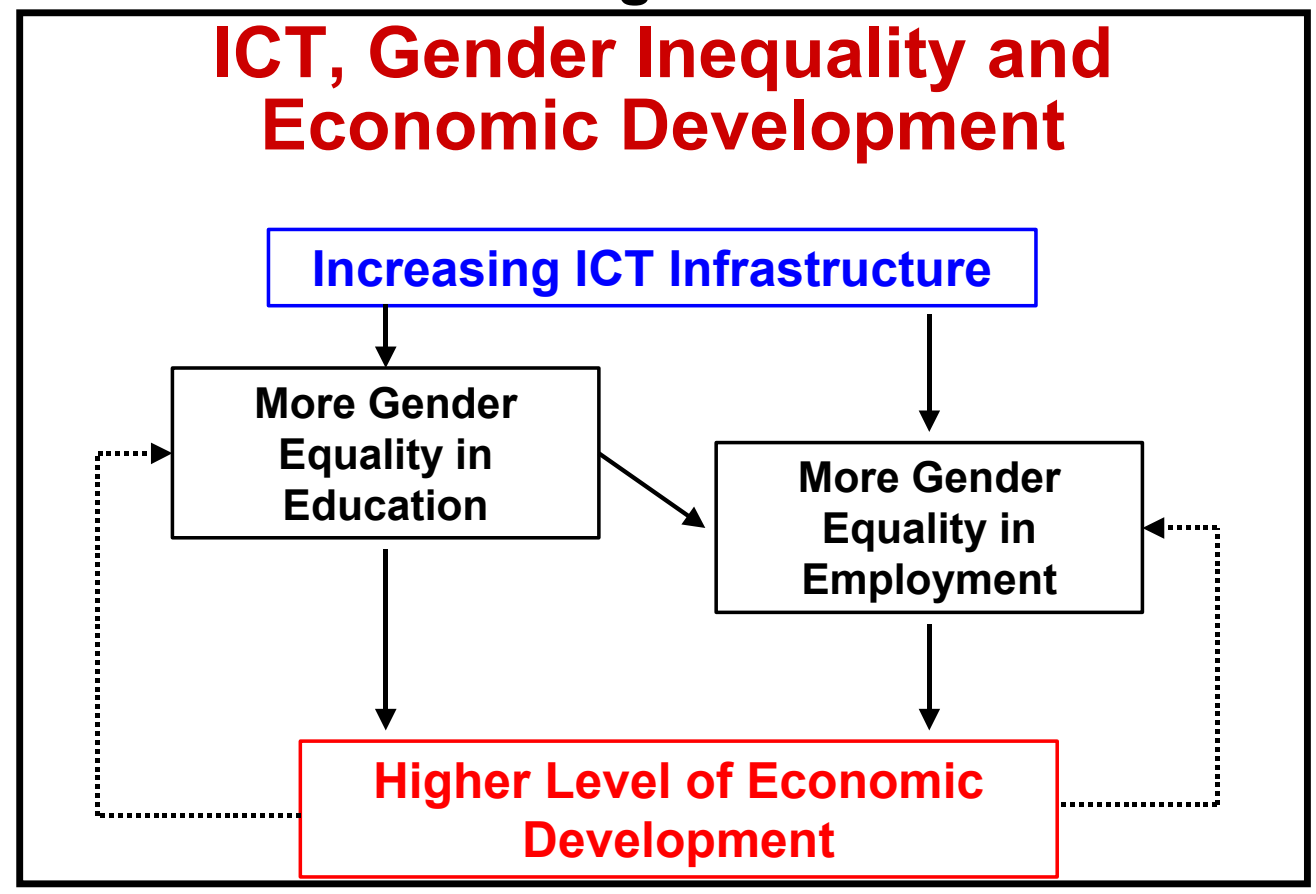

Table 1

OECD Definition of ICT-producing Industries

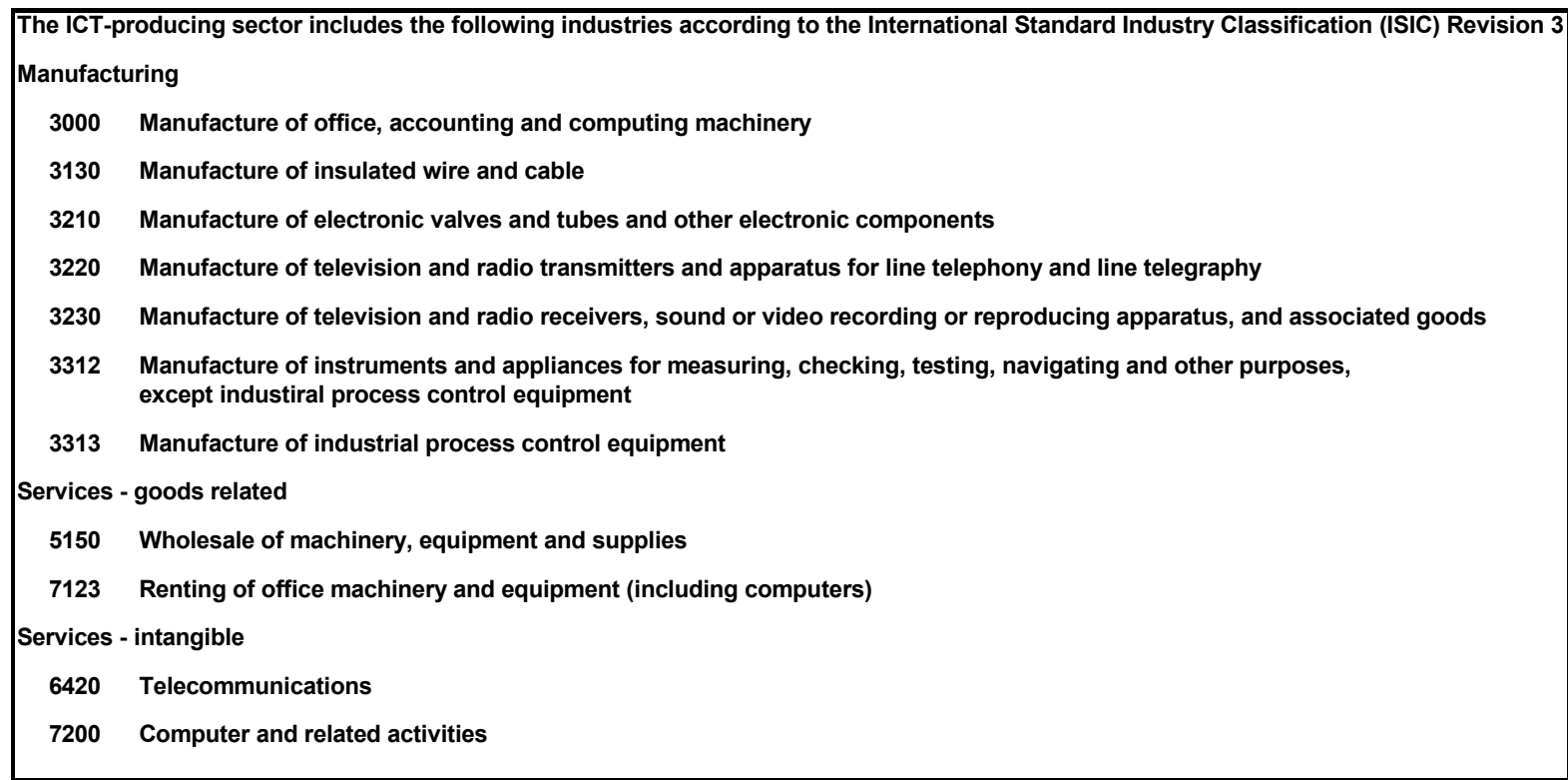




\section{Table 2}

\section{ICT and Gender Equality in Education}

Panel Regressions with Country Fixed-Effects

Dependent Variable: Ratio of Female to Male Primary and Secondary School Students

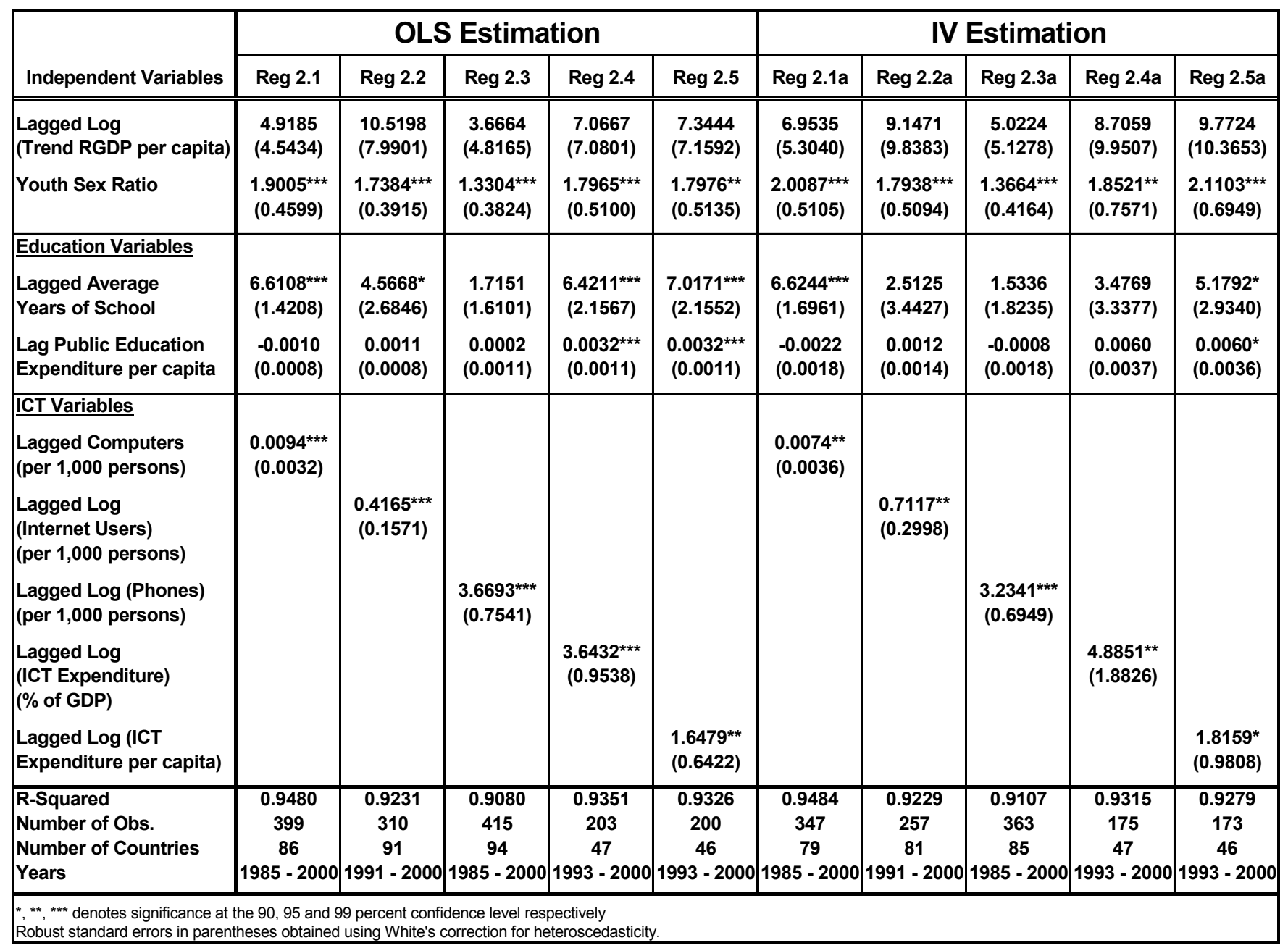




\section{Table 3}

\section{ICT and Gender Equality in Employment}

Panel Regressions with Country Fixed-Effects

Dependent Variable: Ratio of Female to Male Labor Force Activity Rates

\begin{tabular}{|c|c|c|c|c|c|c|c|c|c|c|}
\hline \multirow[b]{2}{*}{ Independent Variables } & \multicolumn{5}{|c|}{ OLS Estimation } & \multicolumn{5}{|c|}{ IV Estimation } \\
\hline & $\operatorname{Reg} 3.1$ & $\operatorname{Reg} 3.2$ & $\operatorname{Reg} 3.3$ & $\operatorname{Reg} 3.4$ & $\operatorname{Reg} 3.5$ & $\operatorname{Reg} 3.1 \mathrm{a}$ & $\operatorname{Reg} 3.2 \mathrm{a}$ & $\operatorname{Reg} 3.3 a$ & $\operatorname{Reg} 3.4 a$ & $\operatorname{Reg} 3.5 \mathrm{a}$ \\
\hline $\begin{array}{l}\text { Lagged } \\
\text { Log (RGDP per capita) }\end{array}$ & $\begin{array}{c}2.0962 \\
(1.5354)\end{array}$ & $\begin{array}{c}5.0638^{* * *} \\
(1.3284)\end{array}$ & $\begin{array}{c}1.6812 \\
(1.3392)\end{array}$ & $\begin{array}{c}5.1645^{\star * *} \\
(1.5274)\end{array}$ & $\begin{array}{l}3.3407^{\star *} \\
(1.5107)\end{array}$ & $\begin{array}{c}1.6919 \\
(1.6143)\end{array}$ & $\begin{array}{c}4.4956^{\star * *} \\
(1.3250)\end{array}$ & $\begin{array}{c}1.9098 \\
(1.3915)\end{array}$ & $\begin{array}{c}4.8790^{* * *} \\
(1.5609)\end{array}$ & $\begin{array}{l}2.6453^{*} \\
(1.4659)\end{array}$ \\
\hline $\begin{array}{l}\text { Lagged Urbanization } \\
\text { Ratio }\end{array}$ & $\begin{array}{l}-0.0578 \\
(0.0424)\end{array}$ & $\begin{array}{c}0.0893 \\
(0.0566)\end{array}$ & $\begin{array}{l}-0.0231 \\
(0.0518)\end{array}$ & $\begin{array}{c}0.0133 \\
(0.0584)\end{array}$ & $\begin{array}{c}0.0563 \\
(0.0568)\end{array}$ & $\begin{array}{l}-0.0640 \\
(0.0436)\end{array}$ & $\begin{array}{c}0.0784 \\
(0.0579)\end{array}$ & $\begin{array}{l}-0.0319 \\
(0.0543)\end{array}$ & $\begin{array}{c}0.0117 \\
(0.0604)\end{array}$ & $\begin{array}{c}0.0645 \\
(0.0593)\end{array}$ \\
\hline Unemployment Rate & $\begin{array}{l}-0.0498^{*} \\
(0.0264)\end{array}$ & $\begin{array}{l}-0.0116 \\
(0.0218)\end{array}$ & $\begin{array}{c}0.0004 \\
(0.0267)\end{array}$ & $\begin{array}{c}0.0087 \\
(0.0261)\end{array}$ & $\begin{array}{c}0.0375 \\
(0.0248)\end{array}$ & $\begin{array}{c}-0.0582^{\star *} \\
(0.0277)\end{array}$ & $\begin{array}{l}-0.0143 \\
(0.0220)\end{array}$ & $\begin{array}{c}0.0028 \\
(0.0264)\end{array}$ & $\begin{array}{c}0.0060 \\
(0.0280)\end{array}$ & $\begin{array}{c}0.0469^{*} \\
(0.0252)\end{array}$ \\
\hline \multicolumn{11}{|l|}{ Education Variables } \\
\hline $\begin{array}{l}\text { Lagged Average } \\
\text { Years of School }\end{array}$ & $\begin{array}{c}2.3179^{\star * \star} \\
(0.7120)\end{array}$ & $\begin{array}{c}2.1607^{\star * *} \\
(0.6658)\end{array}$ & $\begin{array}{c}3.4054^{* * *} \\
(0.4455)\end{array}$ & $\begin{array}{c}3.3438^{* * *} \\
(0.5892)\end{array}$ & $\begin{array}{c}3.0423^{\star * *} \\
(0.5018)\end{array}$ & $\begin{array}{c}2.3360^{\star * \star} \\
(0.7648)\end{array}$ & $\begin{array}{l}1.9973^{\star *} \\
(0.7775)\end{array}$ & $\begin{array}{c}3.6911^{* * *} \\
(0.4604)\end{array}$ & $\begin{array}{c}3.4979^{\star * *} \\
(0.6413)\end{array}$ & $\begin{array}{c}2.8429 * * * \\
(0.5320)\end{array}$ \\
\hline $\begin{array}{l}\text { Lagged Ratio of Average } \\
\text { Years of School }\end{array}$ & $\begin{array}{c}0.0271 \\
(0.0454)\end{array}$ & $\begin{array}{l}0.0762^{* *} \\
(0.0381)\end{array}$ & $\begin{array}{c}0.1282^{* * *} \\
(0.0392)\end{array}$ & $\begin{array}{c}0.0854^{*} \\
(0.0481)\end{array}$ & $\begin{array}{l}0.0798^{*} \\
(0.0418)\end{array}$ & $\begin{array}{c}0.0193 \\
(0.0508)\end{array}$ & $\begin{array}{r}0.0780^{*} \\
(0.0441)\end{array}$ & $\begin{array}{c}0.1320^{* * *} \\
(0.0455)\end{array}$ & $\begin{array}{c}0.0816 \\
(0.0613)\end{array}$ & $\begin{array}{c}0.0710 \\
(0.0471)\end{array}$ \\
\hline \multicolumn{11}{|l|}{ ICT Variables } \\
\hline $\begin{array}{l}\text { Lagged Log (Computers) } \\
\text { (per 1,000 persons) } \\
\text { Lagged } \\
\text { Log (Internet Users) } \\
\text { (per 1,000 persons) }\end{array}$ & $\begin{array}{c}1.4548^{* * *} \\
(0.2228)\end{array}$ & $\begin{array}{c}0.1817^{\star * \star} \\
(0.0557)\end{array}$ & & & & $\begin{array}{c}1.6726^{\star * *} \\
(0.2859)\end{array}$ & $\begin{array}{c}0.2575^{\star \star *} \\
(0.0884)\end{array}$ & & & \\
\hline $\begin{array}{l}\text { Lagged Phones } \\
\text { (per 1,000 persons) }\end{array}$ & & & $\begin{array}{c}0.0048^{* * *} \\
(0.0008)\end{array}$ & & & & & $\begin{array}{c}0.0035^{\star * *} \\
(0.0006)\end{array}$ & & \\
\hline $\begin{array}{l}\text { Lagged ICT } \\
\text { Expenditure (\% of GDP) }\end{array}$ & & & & $\begin{array}{c}0.1286^{*} \\
(0.0778)\end{array}$ & & & & & $\begin{array}{c}0.0809 \\
(0.0806)\end{array}$ & \\
\hline $\begin{array}{l}\text { Lagged (ICT } \\
\text { Expenditure per capita) }\end{array}$ & & & & & $\begin{array}{c}0.0015^{\star \star *} \\
(0.0003)\end{array}$ & & & & & $\begin{array}{c}0.0019^{\star * *} \\
(0.0004)\end{array}$ \\
\hline $\begin{array}{l}\text { R-Squared } \\
\text { Number of Obs. } \\
\text { Number of Countries } \\
\text { Years }\end{array}$ & \begin{tabular}{|c|}
0.9939 \\
616 \\
71 \\
$1981-2001$
\end{tabular} & \begin{tabular}{|c|}
0.9980 \\
475 \\
74 \\
$1991-2001$ \\
\end{tabular} & \begin{tabular}{|c|}
0.9935 \\
707 \\
77 \\
$1981-2001$ \\
\end{tabular} & \begin{tabular}{|c|}
0.9977 \\
360 \\
48 \\
$1993-2001$ \\
\end{tabular} & \begin{tabular}{|c|}
0.9981 \\
353 \\
47 \\
$1993-2001$
\end{tabular} & \begin{tabular}{|c|}
0.9940 \\
611 \\
71 \\
$1981-2001$ \\
\end{tabular} & \begin{tabular}{|c|}
0.9982 \\
470 \\
74 \\
$1991-2001$ \\
\end{tabular} & \begin{tabular}{|c|}
0.9938 \\
702 \\
77 \\
$1981-2001$ \\
\end{tabular} & \begin{tabular}{|c|}
0.9979 \\
356 \\
48 \\
$1993-2001$ \\
\end{tabular} & \begin{tabular}{|c|}
0.9983 \\
350 \\
47 \\
$1993-2001$
\end{tabular} \\
\hline
\end{tabular}

